\title{
PERAN LPD DESA PAKRAMAN GUNAKSA DALAM PEMBANGUNAN DESA ADAT GUNAKSA KECAMATAN DAWAN KABUPATEN KLUNGKUNG
}

\author{
Putri Anggreni ${ }^{1}$ \\ Ni Wayan Suartini \\ Program Studi Manajemen, Fakultas Ekonomi, Universitas Mahendradatta \\ Jl. Ken Arok No. 12, Peguyangan Denpasar Utara, Bali 80115 \\ 1Email: gekcay@gmail.com \\ ${ }^{2}$ Email: suartini59@gmail.com
}

\begin{abstract}
Abstrak - Keberadaan LPD Desa Pakraman Gunaksa dalam kontribusi pembangunan Desa adat Gunaksa merupakan hal yang tidak bisa dibilang kecil. Karena dari segi pembangunan yang belum merata, kondisi jalan yang masih dalam perbaikan serta sektor industri yang kurang. Karena itu peneliti tertarik untuk mengkaji secara mendalam Peran LPD Desa Pakraman Gunaksa dalam pembangunan Desa Adat Gunaksa. Metode penelitian yang digunakan adalah metode penelitian kualitatif dengan teknik wawancara serta mengkaji historis dari perjalanan LPD selama berdiri. Hasil penelitian menunjukkan bahwa LPD Desa adat Gunaksa cukup berperan penting. Bisa dilihat dari segi keuntungan yang $20 \%$ laba setiap tahunnya otomatis menjadi hak milik warga masyarakat Desa adat Gunaksa. Laba atau keuntungan tersebut dipergunakan untuk upacara adat dan proses pembangunan desa secara fisik. Dimana Laba tahun 2017 mencapai Rp.802.057.801,43 yang mana 20\% laba tersebut atau sebesar Rp.160.411.560,29 sudah otomatis menjadi hak milik warga Desa Adat Gunaksa. Perhitungan laba tahun 2017 yang telah dialokasikan dan telah dipergunakan oleh pihak Bendesa adat guna kegiatan upacara adat yaitu prosesi adat Upacara Nandan yang setiap 1 (satu) tahun diadakan serta untuk perbaikan kantor kepala desa serta untuk memperbaiki akses yang sudah tidak layak untuk dipergunakan.
\end{abstract}

Kata kunci: peran, LPD, pembangunan 


\begin{abstract}
LPD existence Pakraman Gunaksa in traditional village development contribution Gunaksa are things that are not exactly small. Because in terms of uneven development, road conditions are still under construction and industry sectors are lacking. Therefore, researchers are interested to study in depth the role of LPD Pakraman Gunaksa in the construction of the village people Gunaksa. The method used is the qualitative research methods by interview and review historical LPD trip during standing. Research shows that traditional village LPD Gunaksa quite an important role. Can be viewed in terms of profits $20 \%$ profit every year automatically become the property of citizens Gunaksa traditional village. Profit or gain is used for traditional ceremonies and village development processes physically. Where income in 2017 reached Rp.802,057,801.43 which is $20 \%$ of the profit or Rp.160,411,560.29 has automatically become the property of residents of the village people Gunaksa. Calculation of profit in 2017 has been allocated and has been used by the indigenous Bendesa to activities ritual is customary procession Nandan ceremony is held every first year as well as for repairs village head office along to improve the access is not feasible to be used.
\end{abstract}

Key words: contribution, $L P D$, development 


\section{PENDAHULUAN}

Indonesia merupakan negara yang memiliki sistem perbankan mikro terbesar di dunia dan juga memiliki banyak LKM komersial yang dalam hal ukuran, ragam, volume, penetrasi pasar dan keuntungannya merupakan yang paling maju di dunia. Pada tahun 1972 Pemerintah Provinsi Jawa Barat dan Sumatera Barat mendirikan beberapa Lembaga Keuangan nonbank yang mereka sebut sebagai Lembaga Perkreditan Kecamatan (LPK) berdasarkan Keputusan Gubernur Jawa Barat No. 171 tahun 1972, dan Lumbung Pitih Nagari atau LPN (organisasi kredit desa) berdasarkan Keputusan Gubernur Sumatera Barat No. 085 tahun 1972. Pada tahun 1984 Kredit Usaha Rakyat Kecil (KURK) didirikan oleh Pemerintah Provinsi Jawa Timur berdasarkan Keputusan Gubernur Jawa Timur No. 197 tahun 1984, dan Pemerintah Provinsi Bali juga mendirikan Lembaga Perkreditan Desa (LPD) pada tahun yang sama berdasarkan Surat Keputusan Gubernur Kepala Daerah tingkat I Bali No. 972 Tahun 1984 tertanggal 1 November 1984, yang lebih lanjut dikukuhkan kembali dengan Peraturan Daerah (Perda) Provinsi Bali No. 2 Tahun 1988 tertanggal 27 Januari 1988. Guna lebih memantapkan kelembagaan LPD diseluruh Bali, Pemerintah Daerah Provinsi Bali kembali mengeluarkan Peraturan Daerah (PERDA) Provinsi Bali No. 8 Tahun 2002, disertai Keputusan Gubernur yang mengatur pendirian, lapangan usaha, modal, organisasi, rencana kerja dan anggaran, pelaporan dan pengwasan serta pembinaan LPD. LPD Bali dianggap sebagai LKM paling sukses di Indonesia, yang telah menunjukkan kelebihannya dalam memobilisasi simpanan dari masyarakat pedesaan dengan mengenalkan simpanan sukarela sejak awal. LPD Bali berbeda dengan lembaga-lembaga lain dalam hal kepemilikan, peraturan, dan operasionalnya. LPD Bali dimiliki oleh desa adat, bukannya oleh Pemerintah Provinsi. Pengaruh desa adat dalam pengaturan operasional dan peraturan LPD sangatlah penting.

Lembaga Perkreditan Desa (LPD) merupakan badan usaha milik desa yang melaksanakan kegiatan usaha di lingkungan desa dan untuk krama desa. Kegiatan-kegiatan yang dilakukan LPD adalah menerima atau menghimpun dana dari krama desa dalam bentuk tabungan dan deposito, memberikan pinjaman hanya kepada krama desa, menerima pinjaman dari lembaga-lembaga keuangan dan menyimpan kelebihan likuiditasnya pada Bank Pembangunan Daerah Bali. LPD sebagai lembaga keuangan desa mempunyai karakteristik khusus yang berbeda dengan lembaga keuangan lainnya, sehingga dalam operasionalnya perlu dilakukan pembinaan dan pengawasan. Lembaga yang berfungsi untuk memberikan pembinaan teknis, pengembangan serta pelatihan bagi LPD adalah Lembaga Perkreditan Desa Kabupaten/Kota (PLPDK). 
Pembinaan dan pengawasan bagi LPD sangat penting untuk meningkatkan kinerjanya sehingga kepercayaan masyarakat desa meningkat. Agar profesionalisme dalam melayani masyarakat golongan ekonomi lemah melalui penyesuaian kriteria kinerja keuangan lebih efektif, diperlukan adanya pedoman atau standar penilaian kinerja keuangan.

Kinerja keuangan adalah prestasi yang dicapai oleh perusahaan dalam suatu periode tertentu yang mencerminkan tingkat kesehatan dari perusahaan tersebut. Kinerja keuangan perusahaan merupakan salah satu dasar penilaian mengenai kondisi keuangan perusahaan yang dapat dilakukan berdasarkan analisis terhadap rasio-rasio keuangan perusahaan. (Keputusan Menteri Keuangan Republik Indonesia berdasarkan keputusan Nomor: 740/KMK/1989 tanggal 20 Juni 1989).

Untuk mengetahui prestasi dan posisi keuangan suatu perusahaan, seorang analis keuangan memerlukan ukuran tertentu. Ukuran yang sering kali digunakan adalah rasio atau indeks yang menunjukkan hubungan antara dua data keuangan. Untuk mengevaluasi kondisi keuangan dan kinerja keuangan perusahaan, analis keuangan harus melakukan pemeriksaan terhadap kesehatan keuangan perusahaan. Alat yang biasa digunakan dalam pemeriksaan ini adalah rasio keuangan yang menghubungkan dua data keuangan dengan jalan membagi satu data dengan data yang lainnya. Kinerja keuangan LPD secara keseluruhan merupakan gambaran prestasi yang dicapai LPD dalam operasionalnya, baik menyangkut aspek keuangan, pemasaran, penghimpunan dan penyaluran dana, teknologi maupun sumber daya manusia. Kinerja keuangan Bank/LPD merupakan gambaran kondisi keuangan Bank/LPD pada suatu periode waktu tertentu baik menyangkut aspek penghimpunan dana maupun penyaluran dana yang biasanya diukur dengan indikator kecukupan modal, likuiditas dan profitabilitas Bank/LPD. Bagi Lembaga Keuangan/Bank dan Lembaga perkreditan Desa/LPD, kinerja keuangan merupakan salah satu faktor yang sangat penting, dalam rangka pengembangan usaha yang sehat dan dapat menampung risiko kemungkinan kerugian. Apabila kinerja keuangan LPD baik, diharapkan dapat meningkatkan pertumbuhan LPD untuk jangka panjang, sebaliknya apabila kinerja keuangan LPD buruk akan dapat menurunkan pertumbuhan LPD.

Asisten Perekonomian dan Pembangunan Setda Badung Dewa Made Apramana, mengungkapkan LPD dikelola dengan landasan Tri Hita Karana. Sistem adat yang kuat menjiwai mental, pola dan sikap dari masyarakat di desa sehingga membuat LPD menjadi lembaga keuangan yang terbilang kuat. Dengan dilandasi sistem adat yang kuat itulah, LPD sebagai lembaga 
keuangan yang modalnya dari swadaya masyarakat, mampu tumbuh dan berkembang di era kekinian. Tidak hanya itu, LPD bahkan telah mampu menopang keuangan masyarakat, khususnya masyarakat miskin yang ada di wilayah Kabupaten Badung.

Bagi LPD Di Kabupaten Klungkung penilaian kinerja keuangan sangat penting dilakukan untuk menilai keberhasilan pengelolaan keuangan LPD terutama kondisi kecukupan modal, kualitas aktiva produktif, likuiditas, dan profitabilitas yang dicapai dalam tahun berjalan maupun tahun sebelumnya dan menilai kemampuan LPD dalam mendayagunakan semua aset yang dimiliki dalam menghasilkan profit secara efisien. Keberadaan LPD di masyarakat desa pakraman telah banyak mengalami peningkatan yang pesat. Lembaga keuangan LPD tersebut mampu meningkatkan potensi masyarakat desa pakraman, dan membantu masyarakat desa pakraman dalam kehidupannya didalam masyarakat desa pakraman. Sebagai contoh cara LPD dapat meringankan beban masyarakat desa pakraman, dapat kita lihat pada Desa Pakraman Kedonganan. Misalnya, tradisi ngaben yang dianggap sebagai kewajiban personal umat Hindu membutuhkan biaya yang cukup besar. Jika kewajiban ini tidak ditunaikan, bisa berkembang menjadi masalah komunitas, bukan lagi masalah personal umat hindu. Disinilah keberadaan LPD sebagai lembaga keuangan masyarakat komunitas memberikan Peran besar dengan menyelenggarakan ngaben massal gratis. Peran LPD dalam membantu masyarakat desa pakraman juga termasuk dalam memberikan dana untuk membangun pura dan pelaksanaan upacara, yang sebelumnya dilakukan dengan dana pribadi masyarakat desa pakraman. LPD juga memberikan beasiswa berupa pendidikan kepada siswa yang berprestasi sehingga dapat melanjutkan pendidikannya kejenjang yang lebih tinggi.

Berdasarkan rentetan keberhasilan tersebut, pengaturan LPD seharusnya dikembalikan kepada identitas kultural desa pakraman, yaitu sifat otonomnya dalam mengatur penyelenggaraan kehidupan rumah tangganya (self regulation). LPD sebagaimana juga desa adat di Bali, diatur dengan peraturan daerah. Permasalahan hukum tersebut, menyebabkan fenomena ini menjadi menarik untuk diteliti.

Menyimak pengertian di atas dan Perda yang secara konstitusi mengatur tentang keberadaan LPD serta lapangan usaha LPD tersebut, maka LPD merupakan badan usaha yang bergerak dibidang ekonomi mempunyai tujuan memperoleh keuntungan, dimana dari keuntungan tersebut dialokasikan untuk: cadangan modal 60\%, dana pembangunan desa adat $20 \%$, jasa produksi $10 \%$, dana pembinaan, pengawasan dan perlindungan $5 \%$, dan dana sosial sebanyak $5 \%$. 
LPD Desa Adat Gunaksa merupakan salah satu LPD yang berlokasi di Desa Gunaksa, Kecamatan Dawan, Kabupaten Klungkung. Wilayah Desa Adatnya adalah merupakan bagian dari Desa Adat Gunaksa. Desa Adat Gunaksa yang dulunya sangat perlu mendapat perhatian pemerintah dalam pembangunan desa, sekarang sudah

berkembang dengan swadaya sendiri dengan bantuan LPD Desa Adat Gunaksa. LPD Desa Pakraman Gunaksa selama tahun 2013 sampai dengan tahun 2017 memiliki keuntungan dengan tren meningkat. Laba tahun berjalan LPD Desa Pakraman Gunaksa dapat dilihat dari tabel berikut :

Tabel 1

Laba Tahun Berjalan LPD Desa Pakraman Gunaksa

Tahun 2013-2017

\begin{tabular}{|c|lc|}
\hline Tahun & \multicolumn{2}{|c|}{ Jumlah Laba } \\
\hline 2013 & Rp. & $467.296 .279,-$ \\
\hline 2014 & Rp. & $514.691 .523,-$ \\
\hline 2015 & Rp. & $554.698 .654,-$ \\
\hline 2016 & Rp. & $701.020 .446,-$ \\
\hline 2017 & Rp. $\quad 802.057 .801,-$ \\
\hline
\end{tabular}

Dari keuntungan tiap tahunnya, LPD Desa Pekraman Gunaksa menyisihkan untuk kepentingan Desa Adat Gunaksa. Penyisihan keuntungan tersebut mempunyai peran dan tujuan untuk pembangunan di dalam bidang ekonomi dan kesejahteraan masyarakat.

\section{KAJIAN TEORI}

Teori peran adalah sebuah sudut pandang dalam sosiologi dan psikologi sosial yang menganggap sebagian besar aktivitas harian diperankan oleh kategori-kategori yang ditetapkan secara sosial (misalnya ibu, manajer, guru). Setiap peran sosial adalah serangkaian hak, kewajiban, harapan, norma, dan perilaku seseorang yang harus
Dari latar belakang tersebut di atas, permasalahannya yang diajukan adalah: Bagaimanakah peran LPD Desa Pakraman Gunaksa terhadap Pembangunan Desa Adat Gunaksa?

Tujuan dari penelitian ini adalah: Untuk mengetahui peran LPD Desa Pakraman Gunaksa terhadap Pembangunan Desa Adat Gunaksa.

dihadapi dan dipenuhi. Model ini didasarkan pada pengamatan bahwa orang-orang bertindak dengan cara yang dapat diprediksikan, dan bahwa kelakuan seseorang bergantung pada konteksnya, berdasarkan posisi sosial dan faktor-faktor lain. Teater adalah metafora yang sering digunakan untuk mendeskripsikan teori peran. 
Peran adalah serangkaian perilaku yang diharapkan pada seseorang sesuai dengan posisi sosial yang diberikan baik secara formal maupun secara informal. Peran didasarkan pada preskripsi peran-peran tersebut (Friedman, 1992).

Pembahasan tentang tata kelola LPD ini terdiri dari pembahasan tentang organisasi dan perencanaan, prosedur rekrutmen, prinsip pengaturan operasional, mekanisme penyaluran pinjaman dan sistem penggajian.

\section{Organisasi dan Perencanaan}

Organisasi LPD tidaklah

rumit. Dengan cara itu proses perencanaan dan organisasi dalam LPD ini dapat berjalan dengan baik dan tidak ada masalah yang dihadapi tidak dapat diselesaikan sendiri. Hal ini membenarkan bahwa struktur organisasi LPD mampu mengimplementasikan kebijakan dan strategi LPD untuk mencapai tujuannya. Kemampuan manajemen internal LPD memperoleh dukungan dari pengawasan dan bimbingan yang diberikan oleh pemerintah lokal pada tiap tingkatan dan oleh Bank BPD Bali.

\section{Prinsip Pengaturan Operasional}

Prinsip ini mencakup peraturan mengenai kecakupan modal (capital adequacy), batas jumlah peminjaman (legal lending limit), cadangan untuk kerugian pinjaman manajemen likuiditas, dan sistem pemeringkatan LPD.

Mekanisme Penyaluran Pinjaman (ketentuan) dan harapan peran yang menerangkan apa yang individuindividu harus lakukan dalam suatu situasi tertentu agar dapat memenuhi harapan-harapan mereka sendiri atau harapan orang lain menyangkut

Dalam kaitannya dengan tingkat bunga, pada tahun 2002 tingkat bunga pinjaman untk pinjaman berkisar antara 27 hingga 33 persen, lebih tinggi dari pada ratarata tingkat bunga bank umum yang hanya 22 persen per tahun pada saat itu peraturan desa adat juga berlaku bagi staf LPD yang melanggar peraturan dan salah dalam mengelola operasional harian LPD, seperti kolusi, korupsi atau manipulasi. Sanksi sosial dapat dikenakan pada mereka. Selain itu, berdasarkan peraturan legal formal, pasal 24 peraturan Daerah No. 8 / 2002 yang menyatakan bahwa staf LPD yang melanggar peraturan dan menyebabkan LPD menderita kerugian keuangan haruslah mengganti kerugian tersebut.pasal 26 yang menerangkan pasal 24 peraturan tersebut menekankan bahwa staf terpidana dapat memperoleh hukuman maksimum 6 bulan penjara atau maksimum denda Rp.5.000.000,-. $\quad$ Singkatnya, gambaran ini menunjukan bahwa institusi informal (seperti normanorma dan sanksi sosial) dan institusi formal (peraturan legal formal) digunakan bersama-sama dalam tata kelola LPD.

Sistem Penggajian 
Sistem penggajian pada LPD secara umum dimaksudkan untuk menstimulasi kinerja yang lebih baik dari stafnya, terutama dalam mengumpulkan pinjaman dan mempromosikan dan melayani tabungan. Diantara manjemen inti LPD, ketua memperoleh gaji paling tinggi, diikuti oleh petugas kasir dan tenaga administrasi. Prinsip penentuan gaji pokok yang didasarkan biaya hidup di desa di mana LPD berada juga tercermin pada kuatnya hubungan antara LPD dan lingkungan sosio ekonominya.

Teori pembangunan dalam ilmu sosial dapat dibagi ke dalam dua paradigma besar, modernisasi dan ketergantungan. Paradigma modernisasi mencakup teori-teori makro tentang pertumbuhan ekonomi dan perubahan sosial dan teori-teori mikro tentang nilai-nilai individu yang menunjang proses perubahan. Paradigma

ketergantungan mencakup teoriteori keterbelakangan (underdevelopment) ketergantungan (dependent development) dan sistem dunia (world system theory). Sedangkan Tikson (2005) membaginya kedalam 3 (tiga) klassifikasi teori pembangunan, yaitu modernisasi, keterbelakangan dan ketergantungan. Dari berbagai paradigma tersebut itulah kemudian muncul berbagai versi tentang pengertian pembangunan.

Pengertian pembangunan mungkin menjadi hal yang paling menarik untuk diperdebatkan. Mungkin saja tidak ada satu disiplin ilmu yang paling tepat mengartikan kata pembangunan. Sejauh ini serangkaian pemikiran tentang pembangunan telah berkembang, mulai dari perspektif sosiologi klasik (Durkheim, Weber, dan Marx), pandangan Marxis, modernisasi oleh Rostow, strukturalisme bersama modernisasi memperkaya ulasan pendahuluan pembangunan sosial, hingga pembangunan berkelanjutan. Namun, ada tema-tema pokok yang menjadi pesan di dalamnya. Dalam hal ini, pembangunan dapat diartikan sebagai suatu upaya terkoordinasi untuk menciptakan alternatif yang lebih banyak secara sah kepada setiap warga negara untuk memenuhi dan mencapai aspirasinya yang paling manusiawi (Nugroho \& Dahuri, 2004). Tema pertama adalah koordinasi, yang berimplikasi pada perlunya suatu kegiatan perencanaan seperti yang telah dibahas sebelumnya. Tema kedua adalah terciptanya alternatif yang lebih banyak secara sah. Hal ini dapat diartikan bahwa pembangunan hendaknya berorientasi kepada keberagaman dalam seluruh aspek kehidupan. Ada pun mekanismenya menuntut kepada terciptanya kelembagaan dan hukum yang terpercaya yang mampu berperan secara efisien, transparan, dan adil. Tema ketiga mencapai aspirasi yang paling manusiawi, yang berarti pembangunan harus berorientasi kepada pemecahan masalah dan 
pembinaan nilai-nilai moral dan etika umat.

Mengenai pengertian pembangunan, para ahli memberikan definisi yang bermacam-macam seperti halnya perencanaan. Istilah pembangunan bisa saja diartikan berbeda oleh satu orang dengan orang lain, daerah yang satu dengan daerah lainnya, negara satu dengan negara lain. Namun secara umum ada suatu kesepakatan bahwa pembangunan merupakan proses untuk melakukan perubahan (Riyadi \& Bratakusumah, 2005). Siagian

memberikan pengertian tentang pembangunan sebagai "Suatu usaha atau rangkaian usaha pertumbuhan dan perubahan yang berencana dan dilakukan secara sadar oleh suatu bangsa, negara dan pemerintah, menuju modernitas dalam rangka pembinaan bangsa (nation building)". Sedangkan Kartasasmita (1994) memberikan pengertian yang lebih sederhana, yaitu sebagai "suatu proses perubahan ke arah yang lebih baik melalui upaya yang dilakukan secara terencana".

Pada awal pemikiran tentang pembangunan sering ditemukan adanya pemikiran yang mengidentikan pembangunan dengan perkembangan, pembangunan dengan modernisasi dan industrialisasi, bahkan pembangunan dengan westernisasi. Seluruh pemikiran tersebut didasarkan pada aspek perubahan, di mana pembangunan, perkembangan, dan modernisasi serta industrialisasi, secara keseluruhan mengandung unsur perubahan. Namun begitu, keempat hal tersebut mempunyai perbedaan yang cukup prinsipil, karena masing-masing mempunyai latar belakang, azas dan hakikat yang berbeda serta prinsip kontinuitas yang berbeda pula, meskipun semuanya merupakan bentuk yang merefleksikan perubahan (Riyadi \& Bratakusumah, 2005).

Pembangunan

(development) adalah proses perubahan yang mencakup seluruh system sosial, seperti politik, ekonomi, infrastruktur, pertahanan, pendidikan dan teknologi, kelembagaan, dan budaya (Alexander, 2005). Portes (1976) mendefenisiskan pembangunan sebagai transformasi ekonomi, sosial dan budaya. Pembangunan adalah proses perubahan yang direncanakan untuk memperbaiki berbagai aspek kehidupan masyarakat.

Menurut Tikson (2005) bahwa pembangunan nasional dapat pula diartikan sebagai transformasi ekonomi, sosial dan budaya secara sengaja melalui kebijakan dan strategi menuju arah yang diinginkan. Transformasi dalam struktur ekonomi, misalnya, dapat dilihat melalui peningkatan atau pertumbuhan produksi yang cepat di sektor industri dan jasa, sehingga kontribusinya terhadap pendapatan nasional semakin besar. Sebaliknya, kontribusi sektor pertanian akan 
menjadi semakin kecil dan berbanding terbalik dengan pertumbuhan industrialisasi dan modernisasi ekonomi. Transformasi sosial dapat dilihat melalui pendistribusian kemakmuran melalui pemerataan memperoleh akses terhadap sumber daya sosialekonomi, seperti pendidikan, kesehatan, perumahan, air bersih, fasilitas rekreasi, dan partisipasi dalam proses pembuatan keputusan politik. Sedangkan transformasi budaya sering dikaitkan antara lain, dengan bangkitnya semangat kebangsaan dan nasionalisme, disamping adanya perubahan nilai dan norma yang dianut masyarakat, seperti perubahan dan spiritualisme ke materialisme/sekularisme. Pergeseran dari penilaian yang tinggi kepada penguasaan materi, dari kelembagaan tradisional menjadi organisasi modern dan rasional.

Dengan demikian, proses pembangunan terjadi di semua aspek kehidupan masyarakat, ekonomi, sosial, budaya, politik, yang berlangsung pada level makro (nasional) dan mikro (commuinity/group). Makna penting dari pembangunan adalah adanya kemajuan/perbaikan (progress), pertumbuhan dan diversifikasi.

Sebagaimana dikemukakan

oleh para para ahli di atas, pembangunan adalah sumua proses perubahan yang dilakukan melalui upaya-upaya secara sadar dan terencana. Sedangkan perkembangan adalah proses perubahan yang terjadi secara alami sebagai dampak dari adanya pembangunan (Riyadi \& Bratakusumah, 2005).

$$
\text { Dengan semakin }
$$
meningkatnya kompleksitas kehidupan masyarakat yang menyangkut berbagai aspek, pemikiran tentang modernisasi pun tidak lagi hanya mencakup bidang ekonomi dan industri, melainkan telah merambah ke seluruh aspek yang dapat mempengaruhi kehidupan masyarakat. Oleh karena itu, modernisasi diartikan sebagai proses trasformasi dan perubahan dalam masyarakat yang meliputi segala aspeknya, baik ekonomi, industri, sosial, budaya, dan sebagainya.

Oleh karena dalam proses modernisasi itu terjadi suatu proses perubahan yang mengarah pada perbaikan, para ahli manajemen pembangunan menganggapnya sebagai suatu proses pembangunan di mana terjadi proses perubahan dari kehidupan tradisional menjadi modern, yang pada awal mulanya ditandai dengan adanya penggunaan alat-alat modern, menggantikan alat-alat yang tradisional.

Selanjutnya seiring dengan perkembangan ilmu pengetahuan, termasuk ilmu-ilmu sosial, para Ahli manajemen pembangunan terus berupaya untuk menggali konsepkonsep pembangunan secara ilmiah. Secara sederhana pembangunan sering diartikan sebagai suatu upaya untuk melakukan perubahan menjadi lebih baik. Karena 
perubahan yang dimaksud adalah menuju arah peningkatan dari keadaan semula, tidak jarang pula ada yang mengasumsikan bahwa pembangunan adalah juga pertumbuhan. Seiring dengan perkembangannya hingga saat ini belum ditemukan adanya suatu kesepakatan yang dapat menolak asumsi tersebut. Akan tetapi untuk dapat membedakan keduanya tanpa harus memisahkan secara tegas batasannya, Siagian (1994) dalam bukunya Administrasi Pembangunan mengemukakan, "Pembangunan sebagai suatu perubahan, mewujudkan suatu kondisi kehidupan bernegara dan bermasyarakat yang lebih baik dari kondisi sekarang, sedangkan pembangunan sebagai suatu pertumbuhan menunjukkan kemampuan suatu kelompok untuk terus berkembang, baik secara kualitatif maupun kuantitatif dan merupakan sesuatu yang mutlak harus terjadi dalam pembangunan."

Dengan demikian dapat dikatakan bahwa pada dasarnya pembangunan tidak dapat dipisahkan dari pertumbuhan, dalam arti bahwa pembangunan dapat menyebabkan terjadinya pertumbuhan dan pertumbuhan akan terjadi sebagai akibat adanya pembangunan. Dalam hal ini pertumbuhan dapat berupa pengembangan/perluasan

(expansion) atau peningkatan (improvement) dari aktivitas yang dilakukan oleh suatu komunitas masyarakat.

METODE
Berdasarkan uaraian diatas, maka jenis penelitian yang dilaksanakan ini bisa dikatakan tergolong ke dalam penelitian kualitatif tipe studi kasus, karena penelitian ini bertujuan untuk mendeskripsikan Peran LPD Desa Pakraman Gunaksa dalam Pembangunan Desa adat Gunaksa Kecamatan Dawan Kabupaten Klungkung.

Metode Penelitian kualitatif yang digunakan pada umumnya bertujuan untuk mengembangkan konsep atau mengembangkan pemahaman dari suatu fenomena, dalam hal ini yaitu Peran LPD Desa Pakraman Gunaksa dalam Pembangunan Desa adat Gunaksa Kecamatan Dawan Kabupaten Klungkung. Jenis data yang diperlukan dalam penelitian ini adalah jenis data primer dan data skunder. Data primer menurut Margono ( 1996) adalah data yang langsung diperoleh dari sumber informasi pertama, seperti data hasil wawancara, data hasil observasi dan sebagainya. Sedangkan menurut Moleong (2007), data primer adalah data yang diperoleh melalui pengamatan berperan serta dan data hasil wawancara langsung dengan informan. Dalam kaitannya dengan dengan penelitian yang dilaksanakan ini, maka data primer yang dikumpulkan adalah data tentang Peran LPD Desa Pakraman Gunaksa dalam Pembangunan Desa adat Gunkasa.

Sedangkan data merupakan data pelengkap sajian data 
primer. Data skunder adalah data yang diperoleh atau dikumpulkan oleh orang yang melakukan penelitian dari sumber-sumber yang telah ada. Data ini biasanya dari perpustakaan atau dari karya ilmiah peneliti terdahulu.

$$
\text { Sementara menurut }
$$

Moleong (2007) dinyatakan bahwa data sekunder adalah data diluar katakata dan tindakan berupa buku, majalah ilmiah, dokumen pribadi, arsip-arsip, majalah dan sebagainya.

$$
\text { Peneltian ini adalah }
$$

penelitian kualitatif dengan design penelitian terfokus pada observational case study. Dalam design penelitian ini cara pengumpulan data yang utama adalah Ex post facto yaitu suatu pendekatan yang digunakan untuk mengkaji suatu permasalahan yang telah terjadi untuk diteliti pada masa sekarang untuk mendapatkan data yang akurat dan jelas sesuai dengan keadaan yang sebenarnya dengan titik perhatian penelitian adalah Peran LPD Desa Pakraman Gunaksa dalam Pembangunan Desa adat Gunaksa.

Setelah pemilihan dan analisis masalah yang akan diteliti, langkah berikutnya yang harus diperhatikan adalah penentuan metodologi penelitian yang akan digunakan sehingga masalah tadi dapat terjawab secara tepat dan tarandalkan kesahihannya (Faisal, 2005). Dalam penelitian ilmiah untuk mendapatkan data yang diperlukan, para peneliti perlu menggunakan metode-metode tertentu untuk mengumpulkan data. Baik buruknya suatu research sebagai tergantung kepada teknik-teknik pengumpulan datanya. Oleh sebab itu, peneliti menggunakan metode observasi, interview, kepustakaan, dan metode dokumentasi.

Tahapan analisis data adalah salah satu tahapan kunci dalam penelitian. Tahap ini baru bisa dilakukan setelah semua data terkumpul.

Masalah yang tidak kalah penting dari apa yang sudah diperoleh dari hasil penelitian adalah pengelolahan data. Dalam penelitian kualitatif analisis data telah dilakukan sejak sebelum memasuki lapangan atau mulai dari persiapan sebuah penelitian sampai akhir sebuah penelitian. Artinya, analisis data telah mulai sejak merumuskan dan menjelaskan masalah, sebelum terjun ke lapangan dan berlangsung secara berkelanjutan sampai akhir penulisan sebuah penelitian. Menganalisis data dalam penelitian kualitatif lebih difokuskan selama proses di lapangan bersama dengan pengumpulan data (Sugiyono, 2006).

Data primer dan data skunder yang diperoleh dari hasil wawancara, observasi dan kepustakaan telah terkumpul akan dipilah terlebih dahulu, dengan segera digarap oleh peneliti yang akan mengolah data tersebut. Pengolahan data tersebut disebut pengolahan data, dan ada pula yang menyebut sebagai sebuah analisis data (Suharsimi, 2002). Adapun langkah-langkah yang ditempuh dalam menganalisis data dalam penelitian ini meliputi: 
Reduksi data, transformasi data, pengelompokkan data, dan penyajian data.

\section{Reduksi Data}

Penelitian ini difokuskan pada Peran LPD Desa Pakraman Gunaksa dalam Pembangunan Desa adat Gunaksa Kecamatan Dawan Kabupaten Klungkung, maka data yang akan dimanfaatkan hanyalah data yang relevan dengan fokus penelitian. Dalam proses mereduksi akan ada pembuangan data terutama data-data yang diperoleh dalam pengumpulan data yang tidak terkait dengan tujuan penelitian.

\section{Transformasi Data}

Transformasi data adalah pengubahan bentuk data menjadi bentuk lain agar efektif dan efisien tanpa mengubah atau menghilangkan substansinya. Data yang ditransformasi dalam penelitian ini adalah jawaban yang diberikan oleh para informan atas pertanyaan yang diajukan pada saat wawancara.

\section{Pengelompokan Data}

Data yang diperoleh dalam pelaksanaan pengumpulan data belum teratur karena di dapat dari berbagai sumber. Misalnya data tentang Peran LPD Desa Pakraman Gunaksa dalam pembangunan Desa adat Gunaksa Kecamatan Dawan Kabupaten Klungkung, maka untuk memudahkan menganalisis dan menarik simpulan, data itu dikelompokkan dalam satu kelompok.

\section{Penyajian Data}

Data yang telah direduksi akan disusun dan ditata dalam satuan peristiwa dan satuan makna yang meliputi: Peran LPD Desa Pakraman Gunaksa dalam Pembangunan Desa adat Gunaksa.

Langkah-langkah yang telah ditempuh diatas akan menghasilkan simpulan yang bersifat sementara. Simpulan yang bersifat sementara itu akan diuji dengan simpulan-simpulan data yang terjaring dari hasil observasi dan wawancara berikutnya. Dari simpulan-simpulan yang bersifat sementara itu akan ditarik simpulan umum secara indukatif sebagai hasil akhir penelitian. Ini berarti sejak semula peneliti telah berusaha untuk mencari makna data yang dikumpulkan.

Terkait dengan hal ini, Nasution (2007) menyatakan, dari data yang diperolehnya sejak awal, peneliti telah mencoba mengambil simpulan. Simpulan itu mula-mula masih tentative, kabur, diragukan, akan tetapi dengan bertambahan data, maka simpulan itu lebih grounded. Jadi simpulan senantiasa harus diverifikasikan selama penelitian berlangsung untuk mendapatkan simpulan akhir sebagai hasil penelitian.

\section{PEMBAHASAN}

Di dalam penghimpunan dana Masyarakat pada LPD Desa Pakraman Gunaksa bersumber dari tabungan dan deposito yang dipungut oleh petugas LPD. Keberhasilan di dalam kegiatan menghimpun tabungan sangat dipengaruhi oleh 
tingkat pendapatan masyarakat, penghasilan desa dan juga tingkat kepercayaan masyarakat terhadap LPD kita.

Kalau dilihat apa yang dicapai pada saat ini, kiranya kepercayaan masyarakat terhadap LPD cukup tinggi walaupun kalah bersaing dengan bank-bank yang memberikan suku bunga yang lebih tinggi dan berhadiah. Namun masyarakat telah menyadari bahwa LPD ini adalah milik bersama.

\begin{abstract}
Adapun tabungan yang berhasil himpun sampai akhir Desember 2017 sebesar Rp.7.402.414.493,- sedangkan pada akhir tahun 2016 sebesar Rp.6.524.380.863,- dan bila dilihat dari angka tersebut, dimana LPD mengalami peningkatan tabungan sebesar $13.45 \%$ dari tahun 2017.
\end{abstract}

\section{Pinjaman yang Diberikan}

Pinjaman yang dapat disalurkan kepada masyarakat pada tahun ini sebesar Rp.9.820.688.500,yang terdiri dari:

Tabel 2

Pinjaman Yang Diberikan

\begin{tabular}{|l|l|c|}
\hline Klasifikasi Pinjaman & Rupiah & Orang \\
\hline Lancar & Rp.8.912.691.000,- & 288 \\
Kurang Lancar & Rp. 786.243.500,- & 18 \\
Diragukan & Rp. $20.672 .000,-$ & 7 \\
Macet & Rp. $101.082 .000,-$ & 16 \\
\hline Jumlah & Rp.9.820.688.500,- & $\mathbf{3 2 9}$ \\
\hline
\end{tabular}

Bila dibandingkan dengan rencana kerja, sasaran yang tercapai $100,06 \%$, kalau dibandingkan dengan realisasi tahun lalu mengalami peningkatan sebesar $12,82 \%$.

1. Pendapatan bunga pinjaman dari nasabah sebesar Rp.1.544.517.835,- berarti $8,77 \%$ di atas target.

2. Pendapatan bunga dari BPD sebesar Rp.69.711.596,43,- berarti sasaran yang tercapai $82,01 \%$.

\section{Pendapatan}

Pendapatan pada tahun 2017 sebesar Rp.1.694.689.101,43,- yang terdiri dari:

3. Pendapatan administrasi kredit yang tercapai pada tahun ini sebesar Rp.63.400.000,- berarti sasaran yang tercapai $68,91 \%$ ini masih ada dampak dari penurunan administrasi dari $2 \%$ ke $1 \%$. 
4. Pendapatan lain-lain yang diperoleh pada tahun ini sebesar Rp.17.059.670,- atau 89,55\% diatas target. Kenaikan ini disebabkan fee dari rekening air.

\section{Biaya}

Biaya yang kita keluarkan pada tahun 2017 sebesar Rp.892.631.300,yang terdiri dari:

1. Biaya bunga tabungan kepada nasabah sebesar Rp.376.052.400,berarti 3,59 \% di atas target (peningkatan tabungan masyarakat).

2. Biaya badan pengawas yang di keluarkan tahun 2017 sebesar Rp.43.850.000,-

3. Biaya Pegawai yang dikeluarkan pada tahun 2017 sebesar Rp.254.283.000,- atau 0,28\% biaya yang dapat ditekan dari anggaran.

4. Biaya kantor yang dikeluarkan pada tahun 2017 sebesar Rp.9.571.100,- atau 73,62\% biaya yang dapat ditekan dari anggaran.

5. Biaya perjalanan yang dikeluarkan pada tahun 2017 sebesar
Rp.3.610.000,- atau 3,14\% biaya diatas target (peningkatan transaksi ke BPD).

6. Biaya penyusutan pada tahun 2017 sebesar Rp.4.660.000,--

7. Cadangan pinjaman ragu-ragu pada tahun 2017 yaitu sebesar Rp.110.000.000,- guna mengantisipasi kredit bermasalah disamping juga untuk pemupukan modal.

8. Biaya lain-lain sebesar Rp.11.669.800.- atau 1,47\% biaya diatas dari anggaran.

9. Biaya pemeliharaan yang dikeluarkan pada tahun 2017 sebesar Rp.4.225.000,- atau $42,25 \%$ dari anggaran.

\section{Laba Usaha}

Dari laba usaha yang tercapai pada tahun 2017 sebesar Rp.802.057.801,43,- atau 6,94\% di atas target dari rencana kerja. Kalau dibandingkan dengan tahun 2016 mengalami peningkatan sebesar $14,41 \%$.

Asset

\section{Tabel 3}

Neraca Per 31 Desember 2017

Aktiva

1. Kas

2. Antar Bank Aktiva

a. Tabungan

b. Deposito

3. Pinjaman

a. Pinjaman yang diberikan

b. Cadangan Piutang Raguragu (-)

4. Aktiva tetap dan Inventaris

a. Harga Perolehan

b. Akumulasi penyusutan
Rp.

55.510.200,-

Rp.1.825.082.189,59, Rp. 800.000.000,00,-

Rp. $\quad 9.820 .688 .500,-$

Rp. 415.021.000,-

Rp. 203.121.175,-

Rp. 166.143.850,$\mathrm{Rp}$ 2.000.000,- 


\begin{tabular}{|c|c|}
\hline 5. Rupa-rupa Aktiva & \\
\hline Jumlah & Rp. 12.125.237.214,59,- \\
\hline \multicolumn{2}{|l|}{ PASSIVA } \\
\hline 6. Modal disetor & 16.700.000,- \\
\hline 7. Cadangan Umum & Rp.2.564.064. 920.16,- \\
\hline 8. Tabungan & Rp. 7.402.414.493,- \\
\hline 9. Deposito & Rp.1.340.000.000.00,- \\
\hline 10. Pinjaman yang diterima & Rp. - \\
\hline 11. Rupa-rupa Passiva/titipan & Rp. \\
\hline 12. Antar Bank Passiva & Rp. $\quad-$ \\
\hline 13. Laba/Rugi & Rp. $\quad 802.057 .801 .43,-$ \\
\hline Jumlah & Rp.12.125.237.214,59,- \\
\hline
\end{tabular}

Tabel 4

Laba Pembagian untuk Pembangunan Desa

\begin{tabular}{|l|c|c|}
\hline Kelian Patus & $10 \%$ & Rp.16. 041.156,03,- \\
\hline Upacara Adat & $40 \%$ & Rp.64.164.624, 12,- \\
\hline Pembangunan Desa & $50 \%$ & Rp.80.205.780, 14,- \\
\hline \multicolumn{2}{|c|}{ Jumlah } & Rp. 160.411.560,29,- \\
\hline
\end{tabular}

\section{Upacara Adat}

Dalam kegiatan upacara dana yang disumbangkan dengan persentase yang demikian bukanlah dana yang besar tetapi mencukupi untuk melakukan suatu uapacara. Biasanya dana tersebut digunakan untuk upacara Nandan. Dimana Upacara ini dilaksanakan tiap 1 (satu) tahun sekali yaitu pada tilem sasih Kedasa, upacara yang dilakukan yakni nebas pitra, atau lazim disebut Nandan. Tak banyak sumber bisa dikorek kenapa upacara itu digelar. Berdasarkan catatan prasasti Tutuan, yang kini tersimpan di Pura Bukit Buluh Desa Gunaksa, tradisi Nandan ini tergolong upacara pitra puja, upacara pemujaan roh leluhur. Di situ tegas dicatatkan, Nandan dimaksudkan sebagai upacara naur sosot atau naur danda sang piutang.

Kendati ada warga di luar Desa Gunaksa ikut menggelar upacara ini, umumnya upacara Nandan cuma digelar warga Tutuan. Tak ada catatan, kenapa warga Tutuan di Gunaksa menggelar upacara naur sosot. Prasasti Tutuan cuma menuliskan sebuah mitos, berkisah tentang kealpaan salah seorang leluhur warga Tutuan bernama I Surakerta, yang membunuh sapi milik I Rare Angon (anak Ni Berit Kuning dari pernikahannya dengan Prabhu Erlangga). Sapi itu bernama Sapu Jagat. Konon ekornya sampai menyentuh tanah, maka dari itu disebut I Sapu Jagat (apan ikutnia nyapu jagat). Disebutkan, sapi ini 
memiliki keunggulan gaib, diyakini sebagai sapi pembawa berkah, siapa saja meminjam sapi ini untuk membajak, tanah menjadi subur, hasil

Berdasarkan sumber lisan, konon I Surakerta berumah di Dauh Baingin, diyakini berada di kompleks Pura Batur, tak jauh dari Banjar Patus, Desa Gunaksa. Dari gelagatnya, I Surekerta sosok yang tak pernah bersyukur "tamak" dan rendah budi.

Diceritakan, I Surekerta sudah begitu sering meminjam sapi Ki Sapu Jagat, toh ia tetap loba, memijam paksa sapi itu, sehingga petani lain tak mendapat giliran. Suatu hari, I Rare Angon menolak permintaan itu. I Surakerta marah, lalu membunuh Rare Angon (tan tiba brahmantyania, neher tinuwek anggania Rare Angon). Sapi diambil paksa, dibunuh dan disakiti (pinejahan linara-lara). Sebelum rebah ke tanah, I Rare Angon sempat mengeluarkan kutukan, "Duh engkau Surakerta, di luar batas perilakumu, tidak memiliki balas budi, hatimu gelap. Saya sungguh tak berdosa padamu, kenapa kau membunuh diriku, sekarang kau kena kutuk diriku: "Jah tasmat! Semua keturunan I Surakerta dan kerabat wajib menghaturkan upacara pedandanan, dilakukan saat bulam mati sasih Kedasa.

Teks asli Kanda Purwanma Tutuan, berbunyi begini: "Ih Surakerta, tan piangga denta mambek, tan hanang darma budi, kewala lupa angidep. Apan ingsun tan adruwe dosa ring kita, mawastu ingsun pinejah dening kita, mangkin moga kita kawastonan panen melimpah, tanaman dijauhkan dari hama (mawastu rahayu pamupun carik ika, tan kamerenan saisining sawah ika).

dening ingsun: "Jah tasmat, sahananing satreh sentanan I Surakerta, tekaning saswangan ta kabeh, wenang angaturaken karya padandanan. Rikalaning tilem sasih kadasa, ring genah ingsun mapendem. Dosa I Surakerta karena telah membunuh I Rare Angon dan Sapi Sapuh Jagat menempatkan roh dirinya dan keturunaannya dalam kedaan sosot, terbelit kutuk hingga tak bisa bebas, bersatu dengan Sang Maha Pencipta. Maka untuk membebaskan roh-nya ia harus menggelar upacara padandanan. Upacara ini mesti dibayar saat Ngusaba Pitra di Desa Gunaksa berlangsung setahun sekali, saat Tilem Sasih Kedasa, bertempat di Pura Dalem Cungkub, konon di tempat ini Rare Angon dibunuh dan dikubur (ring genah ingsun mapendem), maka di tempat ini pula dilakukan upacara puncak Pangusaban dan Padandanan. Biasanya masyarakat di Gunaksa, terutama warga Tutuan, atau desadesa lain seperti Sampalan, Desa Iseh, Karangasem menggelar upacara Nandan usai upacara pangroras, dan ada juga menggelar upacara setelah upacara ngantukang Dewa Hyang. Maka upacara ini menjadi satu rangkaian dengan upacara Dewa Yadnya, yang khusus dilakukan untuk memuliakan dan pembebasan leluhur. Di titik ini upacara Nandan pun dikaitkan dengan kewajiban 
sentana untuk membebaskan roh leluhur dari kutuk Rare Angon.

Hingga kini warga Tutuan di Gunaksa sangat percaya bahwa, Rare Angon (bukan Rare Angon anak Batara Siwa), tetap menjadi penjaga (ameng-amengan) Batara di Pura Bukit Buluh. Sekali waktu ada warga yang melihat Rare Angon tengah meniup seruling sembari mengembala lembu Sapu Jagat. Karena alasan ini pula Rare Angon dan Sapi Sapu Jagat diangkat menjadi lambang Desa Gunaksa. Ada "kutuk" bila upacara tidak dilakukan. orang terpelajar tahu kutuk adalah cara paling ortodok supaya pendukung tradisi bersangkutan tetap yakin. Teks Kanda Purwana Ki Tutuan misalnya menguraikan kutuk itu begini: "Yen kita predo, moga atmania manggih sangsara tan pagenah, tiba ring kawah candra goh muka, siyu tahun ya dadi entip kawah yang tan katebas. Yan amalku hana kadyeng arep ling kui, moga amanggih karahayuan paumahan ta, "tekaning atma ira manggih sadia." Artinya: Jika engkau mangkir, semoga rohnya menemu sengsara, tak mendapat tempat, jatuh ke kawah cadra goh muka, jika tidak ditebus, seribu tahun dia menjadi aking kawah. Apabila dijalankan sebagaimana berlaku sejak dulu, semoga memperoleh kerahayuan, sanak keluarga sejahtera, roh leluhur menemukan kebahagiaan. Seperti apa rangkaian upacara nandan warga Tutuan di Gunaksa? Gambaran pokoknya kurang lebih seperti ini. Sebulan sebelum upacara ngusaba/nandan dimulai, prajuru dan manggala menggelar parum. Paruman atau sangkepan ini biasanya membahas sejumlah persiapan upacara pangusaban dan nandan. Dihadiri semua perangkat desa, kelian banjar, dan pejabat tradisonal yang sampai kini tetap diberi hak dan kewajiban khusus, antara lain; nyungsung sejumlah palinggih di Pura Puseh; semisal, Kunta Rawos, Patinggi, Kagaduhan, Kadangkan, Penyarikan, dan sebagainya. Kini pejabat tradisional itu jarang dilibatkan kecuali sebagai penyaksi upacara semata. Bila ada krama yang menghaturkan upacara penandanan, upacara ngusaba bisa diundur sepanjang satu tilem, yakni saat memasuki Tilem Jiyesta. Jikapun tidak ada warga yang menggelar upacara Nandan, bila ada hambatan, upacara ngusaba boleh diundur sampai hitungan pananggal ping kalih Sasih Jiyesta.

Rangkaian selanjutnya,
sepuluh hari sebelum upacara Ngusaba/Nandan dimulai digelarlah upacara Matuun Sang Hyang. Ada dua acara penting dalam upacara ini, pertama nanceb kober putih di ujung jalan menuju setra. Upacara ini pertanda larangan, bahwa sepuluh hari sebelum ngusaba, masyarakat tidak dibolehkan mengubur jenazah, ngaben dan sebagainya. Wilayah setra berada dalam kondisi proteksi. Maksudnya supaya roh leluhur yang akan diminta turun ke bumi tidak dalam kondisi "tercemar Kesuciannya". Kedua, upacara matuun Sang Hyang sendiri, 
dilakukan di Pura Dalem Pakenca. Bagi warga yang menggelar upacara nandan akan mendatangkan seorang dasaran/tapakan atau Jero Seliran ke Pura Dalem Pakenca. Nah, kehadapan Jero Dasaran atau Tapakan inilah si penggelar upacara nunasang/memohon nama-nama roh leluhur yang akan dibebaskan lewat upacara Nandan. Dan sekalian lewat upacara matuun Sang Hyang ini si penggelar upacara "mengecek" keberadaan leluhur-leluhurnya, siapasiapa yang belum atau sudah terbebaskan dari sosot Rare Angon. Di situ lalu si sentana (keturunanannya) menyatakan

Selain mapegatan, mereka yang menggelar upacara nandan dikenai sejumlah kewajiban, diantaranya: bayar utang- utang, menghaturkan sangu buat prajuru desa, serta kewajiban administrasi lain soal penanjung batu yang aturannya tersurat dalam awig-awig desa.

Dalam acara mapegatan ada imba tulis baku yang diterima penyarikan desa. Imba tulis itu berbunyi sebagai berikut: "Atur ulun ring paduka Batara, wenten atur ulun ne samenten ring paduka Batara, kasadian pinunas ulun ring paduka Batara, puniki panawuran ulun, pegat saperantasan, muwah panawuran ulun ring trena-treni, tarulata, gulma jenggama, mangkin ulun tan wenten mautang ring paduka Batara, paduka Batara tan wenten mapihutangan ring ulun, muwah ring sentanan ulun, muwah saputraputrakan ulun, apan sampun puput dengan tulus baik secara sekala maupun niskala bersedia menebus sosot leluhur. Buit.Tiga hari sebelum upacara Ngusaba/Nandan dilakukan upacara Nyaak. Warga yang menggelar atau menghaturkan upacara panandanan membawa serta puspa lingga, simbol roh leluhur yang akan diupacarai di Pura Dalem Pakenca. Upacara dipuput pamangku setempat. Acara inti di sini adalah maktiang puspa, simbol roh leluhur dengan runtutan upacara mapegatan. Seluruh aparat desa hadir sebagai saksi terutama penyarikan (juru tulis) akan mencatat siapa-siapa nama roh leluhur yang diupacarai.

panawuran ulun ring paduka Batara, puniki penawuran ulun ring dina anu, tanggal anu, sasih anu, ingkel anu, rah anu, isaka anu, titiang I anu, sakling anu."

Dengan begitu seluruh utang roh leluhur terlunasi dalam upacara mapegatan itu. Lalu kenapa prajuru desa ikut penerima dan menyaksikan upakara mapegatan? Di sini orang dihadapkan pada pemahaman simbolik, prajuru itu dianggap wakil dewata. Dalam upacara Nyaak disertakan kurban sapi jaga-jaga, sapi ini dikurbankan oleh desa. Sapi yang dipakai kurban adalah sapi cula, sapi yang telah dikebiri. Sapi ini kurban pengganti sapi yang dibunuh I Surakerta bernama Sapu Jagat. Sapi Jaga-Jaga ini diarak sepanjang jalan desa, dilukai, darahnya dicipratkan di Jaba Pura Puseh dan sepanjang jalan desa. Boleh jadi sapi ini juga 
dianggap sebagai caru pemberi tenaga untuk mengharmonikan dan menyucikan kembali wilayah desa. Pada upacara Nyaak ini puspa lingga, simbol roh leluhur yang telah usai melakukan upacara mapegatan di Pura Dalem Pakenca diharapkan sempat mapapas (berpapasan) sertamerta memegang tali sapi Jaga-Jaga yang baru saja datang dari Pura Puseh. Dengan demikian terhampuni pula seluruh sosot leluhur atas kutuk Rare Angon, dan lunas pula kewajiban sentana (keturunan) kehadapan roh leluhur. Sampai di sini upacara Nyaak dianggap selesai untuk selanjutnya sapi jaga-jaga dibawa ke sebuah tempat bernama Buit (di halaman SD No.3 Gunaksa). Di sini sapi disembelih, kepalanya diaturkan pada penguasa Buit, konon berwujud manusia besar bernama Panji Landung.

Dulu bangkai sapi itu dibiarkan busuk di tempat, hingga wilayah itu penuh bau busuk. Sejumlah sekaa tuak mencuri-curi daging itu. Inilah yang menjadi alasan kemudian daging sapi itu dibagi-bagi kepada krama banjar. Tapi kemudian ada kejadian aneh, sejumlah kasus pembunuhan terjadi di Gunaksa. Konon menyebabnya penguasa Buit marah, dan kini daging sapi Jaga-Jaga itu tidak lagi dibagi-bagi. Seterusnya bangkai sapi dikubur di tempat. Kenapa sapi disembelih di wilayah Buit? Ada dugaan di sinilah Surakerta cs. menyiksa membunuh sapi Sapu Jagat itu. Rentetan upacara berikutnya adalah ngeladang tangluk, pemanggilan roh leluhur dari belengu hukuman. Dilakukan pada hari panampahan ngusaba, sehari menjelang acara puncak. Upacara digelar di Setra Desa, menyertakan sejumlah sarana semisal, nasi takilan, seekor godel dandanan, sejumlah alat-alat bertani; bajak, tenggala dan sejumlah uang kepeng serta sarana lain. Saat ngeladang tangluk, puspa, simbol roh leluhur juga diiring serta, dihadiri aparat desa. Ritual utama upacara ini adalah memanggil roh leluhur yang akan diupcarai. Sesaat sebelum pemanggilan, roh leluhur dianggap tengah menjalani "hukuman", mereka dianggap sedang menjalankan kewajiban membajak, menyabit rumput layaknya menjalani kerja rodi. Maka secara simboli juga dilakukan serentetan upacara bertani, seperti membajak, ngelampit, menyabit, dsb.

Dalam upacara ini roh-roh ditebus kehadapan Batara Prajapati dan Batara Rare Angon, supaya rohroh itu dibebaskan dari hukuman, dibebaskan dari ikatan sosot. Di sini, mereka yang menggelar upacara nandan diwajiban membayar pada prajuru desa berupa panumbas padang (rumput), panumbas takilan (bekal), dan sebagainya. Keluarga bersangkutan kemudian memanggil nama-nama yang akan dibebaskan dalam upacara Nandan esok hari. Memasuki upacara puncak, digelar di Pura Pangulun Setra Dalem Cungkub, menyertakan aturan banten laapan. Yang utama adalah rangkaian mapurwa daksina, mengusung keliling, lumbung (simbol roh lakilaki) kumaligi (simbol roh 
perempuan) mengelilingi pelataran pura searah jarum jam. Upacara dipuput pemangku yang diberi wewenang. Lumbung yang dihias meriah itu berisi serangkaian; beras lima warna, benang, kelapa, uang kepeng,dihias orti (reringgitan janur penuh simbolik), serta perlengkapan lain.

Lumbung dan kumaligi diarak dalam rangkaian mapurwa daksina, di mana masing-masing lumbung itu diantar satu godel (anak sapi) yang baru bertanduk aguli, sebesar ibu jari. Godel-godel inilah diyakini mengantar (Nandan) sang roh ke alam pembebasan. Kenapa aguli? Bisa jadi supaya mudah diisi benang tri datu dan uang kepeng. Usai mapurwa daksina, satu ekor godel disemblih palinggih Hyang Gagak. Godel yang dihaturkan itu bernama I Sankur Urung. Momen terakhir dari puncak panandanan ini adalah pamasmia, pembakaran puspa lingga, abunya ditanam di belakang Pura Dalem Cungkub. Bagi warga Tutuan abu puspa lingga itu ditanam di Pura Dalem Kangin. Dengan demikian upacara Nandan dianggap usai, tinggal dilanjutkan dengan tiga kali upacara nyenuk dimana berturut-turut setiap tahun dilakukan.

Dari seluruh rangkaian upacara itu sesungguhnya tersirat makna, bahwa warga Tutuan di Gunaksa berniat menaikkan status leluhurnya ke jenjang lebih tinggi, dari status Dewa Hyang menjadi Sri. Dengan harapan beliau senantiasa melimpahkan kesejahteraan, "ngamertanin"... sentananya.

Dari serangkain upacara yang dilakukan tak jarang dana bantuan yang telah dibagi dari keuntungan LPD setiap tahunnya masih dirasa kurang sehingga ada tambahan dari pihak Kepala Desa.

Tabel 5

Rincian Dana Pengeluaran Upacara Nandan Hingga Akhir

\begin{tabular}{|c|c|}
\hline $\begin{array}{l}\text { Sumbangan Keuntungan } \\
\text { LPD }\end{array}$ & Rp. 64.164.624, 12,- \\
\hline $\begin{array}{l}\text { Sumbangan Dari Kepala } \\
\text { Desa }\end{array}$ & $6.500 .000,-$ \\
\hline Jumlah & Rp. 70.664.624,12,- \\
\hline
\end{tabular}

Untuk mengetahui sehat

tidaknya LPD Desa Pakraman

Gunaksa bisa dilihat pada Analisis

Rasio Laporan keuangan tahun 2017.

Untuk evaluasi ratio Pencapaian LPD

tahun 2017 adalah sebagai berikut :
1. Operating Profit Margin Ratio

$\frac{\text { Laba Usaha }}{\text { Pendapatan }}=\frac{802.057}{1.694 .687} \mathrm{x}$

$100 \%=47,33 \%$

Dengan Operating Profit

Margin Ratio 47,33\% 
menunjukkan bahwa LPD masih memiliki kemampuan yang baik untuk menghasilkan laba usaha.

2. Cost Coverage Ratio (CCR) $\frac{\text { Pendapatan }}{\text { Biaya }}=\frac{1.694 .687}{892.630} \mathrm{x}$ $100 \%=189,85 \%$

Dengan Cost of Coperage Ratio (CCR) 189,85\%, maka dapat disimpulkan bahawa usaha LPD masih perlu meningkatkan efisiensi atau meningkatkan pendapatan melalui pinjaman masyarakat.

3. Liquiditas ratio

Dengan LDR 86,73\% Usaha ini sebenarnya sudah berjalan baik, namun masih bisa diupayakan melalui cadangan yang telah

\section{PENUTUP}

\section{Kesimpulan}

Dari apa yang telah disajikan dalam penelitian ini dapat disimpulkan bahwa sejak berdirinya LPD setiap tahunnya selalu mendapat keuntungan dengan persentase meningkat dan dalam setiap tahunnya pula LPD telah menyetor kepada Desa Adat Gunaksa sesuai dengan persentase yang ditelah ditetapkan yaitu $20 \%$ dari keuntungan yang diperoleh dari laba LPD Desa Pakraman Gunaksa. Laba tersebut dikelola dengan baik sesuai dengan kebutuhan masyarakat baik dalam kegiatan upacara adat maupun dalam proses pembangunan di Desa Adat Gunaksa.

Secara umum tujuan dan sasaran usaha Lembaga Perkreditan Desa (LPD) Desa Pakraman Gunaksa $\frac{\text { Alat Liquiditas }}{\text { Hutang Lancar }}=\frac{2.680 .592}{7.402 .414} \mathrm{x}$ $100 \%=36,21 \%$

Dengan tingkat liquiditas di atas 20\% masih bisa ditingkatkan pinjamannya untuk bisa tercapainya tingkat rentabilitas yang lebih tinggi.

4. Loan Deposit Ratio (LDR) Pinjaman yang diberikan Dana yang diterima + Modal $=\frac{9.820 .688}{11.323 .180} \times 100 \%=86,73$ $\%$

sudah bekerja secara sistematis dan optimal sehingga semua sistem perencanaan, pengorganisasian dan pelaksanaan kerja terkoordinasi dengan baik antara pengelola, pengawas, dan aparatur desa. Hal-hal ini terbukti dengan adanya kepercayaan masyarakat menabung uangnya dan peningkatan jumlah pinjaman dari masyarakat ke LPD. Sehingga dalam sumbangan keuntungan yang setiap tahunnya di berikan oleh LPD ke Desa Adat Gunaksa selalu dalam kisaran angka naik bukan malah turun. Keuntungan yang disumbangkan untuk pembangunan Desa tersebut telah dipergunakan dengan sebaik-baiknya untuk keperluan masyarakat walau dalam persentase yang masih kecil tetapi bisa merata untuk semua lapisan masyarakat dialokasikan untuk memaksimalkan tingkat rentabilitas. 
Jurnal Satyagraha, Vol. 01, No. 02, Agustus 2018 - Januari 2019 ISSN : 2620-6358

Saran

Adapun beberapa saran yang penulis dapat berikan terkait dengan hasil penelitian ini adalah sebagai berikut:

1. Sebaiknya para Prajuru Desa Adat, Desa Dinas dan Badan Pengawas LPD ikut bersama-sama mensosialisasikan keberadaan LPD baik melalui sangkepan di masing-masing Balai Banjar maupun dalam bentuk pertemuan lainnya, baik tentang kepemilikan, fungsi dan manfaat LPD bagi seluruh masyarakat. Mengenai kredit bermasalah (macet) diharapkan bantuan dari Bendesa Adat untuk dikoordinasikan dengan badan Pengawas LPD maupun Prajuru Desa adat Gunaksa, sehingga mendapat jalan keluar atas permasalahan tersebut supaya tidak menjadi panutan bagi kredit yang lancar.

2. Walaupun pelaksanaan tata kerja ini sudah baik, tetapi masih perlu peningkatan dan pengembangan pelayanan serta kebijakan, sehingga peran dan tujuan LPD benarbenar dapat dirasakan oleh masyarakat dan mampu menggerakkan ekonomi perdesaan secara lebih baik.

3. Realisasi pemanfaatkan kredit yang masih dalam kisaran $23,95 \%$ dari jumlah penduduk (KK) masih tergolong kecil, hal ini perlu kerja keras dan kebijakan bagi semua aparatur desa sebagai mandat pemilik usaha Desa Adat, sehingga masyarakat termotivasi menyimpan dan memanfaatkan dana LPD sebagai modal usaha.

4. Lembaga Perkreditan Desa (LPD) adalah Soko Guru perekonomian dan pembangunan di Desa Adat Gunaksa, diharapkan mampu berkompetisi dengan usaha jasa keuangan yang lain dengan meningkatkan pelayanan purna jual, simpati, ramah dalam pelayanan dan menjunjung tinggi transparasi serta akuntabilitas usaha dan komitmen terhadap aturan yang berlaku. Mengingat perkembangan dunia usaha yang semakin komplek dan teknologi semakin modern, maka diharapkan untuk tahun berikutnya dapat meningkatkan anggaran untuk dana pembangunan desa sehingga peran LPD Desa Pakramaan Gunaksa dalam pembangunan Desa Adat Gunaksa semakin maksimal.

\section{DAFTAR PUSTAKA}

Alexander, Abe. 2005. Perencanaan Daerah Partisipatif. Pembaharuan: Yogyakarta.

Arikunto, Suharsimi. 2002. Prosedur Penelitian: Suatu Pendekatan Praktek. RinekaCipta: Jakarta.

Bratakusumah, Deddy Supriady \& Riyadi. 2005. Perencanaan Pembangunan Daerah. PT. Gramedia Pustaka Utama: Jakarta.

Faisal, Abdullah M. 2005, Manajemen Perbankan Teknik Analisis Kinerja Keuangan Bank. Universitas Muhamadiyah Malang.

Friedman, Marilyn M. 1992. Family Nursing.Theory \& Practice. Third Edition. EGC: Jakarta.

Kartasasmita, Ginanjar \& Siagian. 1994. Pembangunan Infrastruktur: Konsep Dan Implikasi. Seminar Pembangunan. Fakultas Ilmu Sosial 
Jurnal Satyagraha, Vol. 01, No. 02, Agustus 2018 - Januari 2019 ISSN : 2620-6358

Dan Politik Universitas Gadjah

Mada: Yogyakarta.

Margono, 1996, Metodologi Penelitian

Pendidikan. PT Rineka Cipta:

Jakarta.

Moleong, Lexy J. 2007. Metode Penelitian

Kualitatif. Remaja Rosdakarya. Bandung.

Nasution, Zulkarnaen. 2007. Komunikasi Pembangunan Pengenalan: Teori Dan Penerapannya. Yang Menerbitkan PT Raja Grafindo Persada: Jakarta.

Nugroho, Iwan \& Dahuri, Rochmin. 2004. Pembangunan Wilayah: Perspektif Ekonomi Dan Lingkungan. LP3ES: Jakarta.

Portes, Alejandro. 1976. On the Sociology of National Development: Theories and Issues. American Journal of Sociology.

Sugiyono, 2006. Statistika Untuk Penelitian. Alfabeta: Bandung.

Tikson, Deddy T. 2005. Indikator-indikator Pembangunan Ekonomi. http://ecozon.html. Diakses pada: Minggu, 15 Juli 2018. 